Caint aint Abel, PASTEL ON BROWN PAPER BAG

(from Passionate Visions

Self-Taught Artists from 1940 to the Present San Diego Museum of Art, El Prado, Balboa Park)

However God made thingks knowd He made knowd He wanted Blood which Abel brought in the Tupperware of his hands from the lamb he kilt and God sait right Abel but to Caint He sait no your harvest aint what I want but the Blood which foreshadows Jesus (God says I'm goint to get an A on my story the structure with no sudden turns you know but plotted for)

and if I can speak honestly with you God as instructor of this writing class a little hard to take I mean you won't do nothingt but have it your own way you're uncompromising if I can say so I mean I decide what works for me if I have to jiggle the table a little well so does everybody else we find a time now of trouble everybody suing and saying so what it wasn't their fault just like no brother's keeper.

\title{
Blue House with People, Bill Traylor, COLORED PENCIL ON CARDBOARD
}

(Or Jum kicking the roof)

I watched the step of someone on the roof the chimney tall you could desize it with your words he rode over its back to plow a field the wild truth seed of God the next infictive. It was a pure step to ask the birds to spread their wings for a tablecloth as if it were a holy ghost meeting and the Lord dressed a stork with dolls and gave the birds your crumbs saying birdie birdie megwetch for your wings. 